23

\title{
Kidnapped Narratives: Mobility without Autonomy and the Nation/ Novel Analogy
}

\author{
Deborah Jenson
}

What does it augur when kidnappings are part of the primal scene of postcolonial nation building and self-representation? In this chapter, I explore the emblematic nature of kidnapping in the African diasporan colonial encounter with the conditions of textual and print culture. As a point of departure, let us consider an episode from the new millennium in which this history of kidnapped narratives was evoked. The 2004 Bicentennial in Haiti was supposed to have inaugurated a year of celebration and commemoration of the 1804 Independence and its global legacies of African diasporan self-emancipation and nineteenth century decolonization. Instead, in the morning of February 29, Haitian President Jean-Bertrand Aristide was reported to have resigned, and to have left the country under American military escort for an unknown destination. By March 1, the plane carrying Aristide and his American-born wife Mildred had landed in the former French colony of the Central African Republic. "I was forced to leave," the Haitian leader said in a phone call to associates in the US (McLaughlin, 2004). In an address to the Haitian people broadcast on Telehaiti in Haiti, Aristide formulated a sort of descriptive maxim: his departure had been "a modern way to have a modern kidnapping" (Slevin and Wilson, 2004). Later he nuanced the description further as "a geo-political kidnapping, terrorism disguised as diplomacy" (Aristide, 2004). (A common witticism promptly emerged to describe the confluence of kidnapping and coup: a "coupnapping.")

Aristide then adapted to his own plight the memorable line pronounced by the famous Revolutionary leader Toussaint Louverture on the occasion of the latter's kidnapping by the French government in June 1802. Toussaint had said, in Gonaives where he was embarked for his exile and imprisonment in France, "In overthrowing

A Companion to Comparative Literature, First Edition. Edited by Ali Behdad and Dominic Thomas.

(C) 2011 Blackwell Publishing Ltd. Published 2011 by Blackwell Publishing Ltd. 
me, they have uprooted, in Saint-Domingue, only the trunk of the tree of the liberty of the blacks; it will grow back because its roots are deep and numerous. ${ }^{1}$ Aristide began by citing Toussaint and then, situating himself in "the shadow of Toussaint L'Ouverture, the genius of the race," he hybridized the original: "I declare in overthrowing me they have uprooted the trunk of the tree of peace, but it will grow back because the roots are Louverturian." 2 From that point on, Aristide's bicentennial billboards in the capital Port-au-Prince, adorned with back-to-back images of himself and Toussaint, proclaiming "Two Men, Two Centuries, The Same Vision," took on new meaning.

Aristide's allegations of kidnapping, whatever their ultimate truth or falsity, made history. Creole linguist Bryant Freeman called Aristide's highly disputed February 28 kreyòl resignation letter "one of the three most important historic documents in the history of Haiti" (Byrd, 2004). ${ }^{3}$ They continue to resonate as a symbolic kidnapping of political process in a former colony inhabited by the descendants of self-emancipated slaves. The mimetic backdrop of the Haitian Revolution and the Haitian Independence - 1804 in 2004 - load this allegation of bicentennial kidnapping with the historical weight of a centuries-old struggle for black freedom and equality in the Western hemisphere. And like the roots of Toussaint's fabled "tree of liberty," the foundations of kidnapping as a form of colonial violence are numerous and deep.

Liminal and urgent narratives of kidnappings are representative of the dynamics of self-representation in an African diasporan population whose forced migration was shockingly reiterated in Napoleonic kidnappings within the families of Haitian Revolutionary leaders. This chapter will analyze the complex narrative of the kidnapping of the oldest son and sister-in-law of Haitian King Henry Christophe. Invoking the work of Benedict Anderson to broach the intrusion of layers of African diasporan and Haitian Revolutionary kidnappings into the relationship between novel and nation in the imagining of New World communities, I will argue that the history of kidnapping points to a different model of narratives in Haitian Revolutionary and early independence history: kidnapped narratives. This is a comparative literature field situated at the violent interstices of national literatures and the literature of the black Atlantic.

\section{The African Diaspora in Triangular Trade and the Intercultural Modalities of Kidnapping}

Just as Aristide's charges of kidnapping beg a "flash back" to the Haitian Revolutionary era, kidnappings within the families of Haitian Revolutionary leaders require contextualization within the mass kidnappings in the previous two centuries of the colonial slave trade. Kidnapping (enlèvement or ravissement in French) was the traumatic starting point of eventual creole or hybridized identity for the African diaspora in the Caribbean. It figures in virtually all family histories related to the New World angle of the triangular slave trade, and was a fundamental mechanism of the large-scale transnational 
movement of populations in the colonial era. (Aristide's story simply involves an odd reversal of the directionality of colonial kidnapping, as Cilas Kemedjio has noted. The "modern kidnapping" described by Aristide was a kidnapping back to Africa rather than from it, symbolic of an attempt to put black power back in the continental Pandora's box from whence it came.)

As Prosper Mérimée’s 1829 story “Tamango” brutally shows, the movement of large populations through the Middle Passage involved individual African profiteers partnering with the system of the Western slave trade. Through these kidnappings, Africans were pitched from a world of shared languages, cultures, and genealogies, to the near-absolute disruption of identity and representational structures that Orlando Patterson has described as "social death," from which a new social existence could only emerge like a phoenix. In the context of ravished individual and diasporan trajectories, the politics of the inhabitation of space are porous, violent, chaotically opportunistic, traumatic, and metamorphic. They frame a zone of inscrutable relations between law and non-law, in which anthropological structures of exchange and sacralization of familial bonds are negated wholesale; a zone in which, in other words, the way that communities "imagine" themselves, from the family to the tribe to the regional geopolitical and linguistic entity, has been subject to the severe stress of arbitrary nullification.

The drama of kidnapping into enslavement was well documented by Western observers of the colonial system from the early phases of Caribbean colonial exploitation. J.-B. Labat, in his famous late seventeenth/early eighteenth century Caribbean travel narrative, cited four categories of Africans forcibly brought to the New World as slaves. The first three categories represented a minor proportion of slaves: wrong doers; prisoners seized in local wars; and the personal slaves of princes who decided to or were compelled by necessity to sell them. The fourth category, far and away the largest, consisted of those who were randomly kidnapped for their human commercial value:

Those that they steal away, either by order or with the consent of princes, or by certain thieves, called merchants, who kidnap everything they can catch in the way of men, women, and children, and take them to a ship or a merchant's establishment, where they are marked with hot irons and put into chains for security. ${ }^{4}$ (Labat, 1993: p. 222)

Labat was in no way alone in his contemporaneous recognition of the linkage between kidnapping and slavery; among the many texts that protest kidnapping in the Atlantic slave trade are Willem Bosman's Kidnapping, Enslaved, and Sold Away, and John Newton's Kidnapping and Retaliation. ${ }^{5}$

And yet, in counter-distinction to this specificity of kidnapping in the African slave trade in the post-Columbian New World, kidnapping as intercultural movement is also, paradoxically, arguably at the very foundations of what we associate with "civilization." The name "Europe" itself derives from a mythological scene of a sort of Europeanization by kidnapping. In the myth of Europa, the Phoenician princess of 
that name, wandering along a beach, was persuaded by Zeus, disguised as a snowy white bull, to ride upon his back. The ride turned into an abduction/ravishment, as Zeus carried the princess across the Mediterranean to Crete, where she became the mother of Minos, Lord of Crete. Norman Davies points out that among the connotations of Europa's ride is the movement of knowledge and reading practices from East to West, locating the cultural identity of Europe in a sort of kidnapping, ravishment, and familial merger of cross-cultural influences: "Zeus was surely transferring the fruits of the older Asian civilizations of the East to the new island colonies of the Aegean ...". (Davies, 1996: p. xvi).

Europa's ride provides the mythical link between Ancient Egypt and Ancient Greece. Europa's brother, Cadmus, who roamed the world in search of her [...] was credited with bringing the art of writing to Greece. (Davies, 1996: p. xvi)

On a mythological level, the origins of European civilization lie not in a founding nationalist scene, but in this involuntary hybridization that evokes the tension between force and exchange in colonialism.

The sheer scale of the phenomenon of kidnapping in the modern colonial slave trade, and its overlap with other forced and unforced migrations that have ceaselessly reshaped boundaries of ethnicities and other communities into diasporan trajectories, makes it a fertile testing ground with regard to Benedict Anderson's famous analogy between nation and novel in the 1983 Imagined Communities. Anderson argued that within the modern print cultural convergence of capitalism and technological dissemination, the novel highlighted a synchronic temporality that simultaneously characterized the nation's self-concept. In Pheng Cheah and Jonathan Culler's description, temporal mimesis in the novelistic narration overlapped with "the simultaneity that allows one to imagine a limited sovereign community beyond face-to-face relations." It goes on to say the nation is supported through the novel's "interpellation," its readers into an omniscient "symbolic mapping of external social space" (Cheah and Culler, 2003: p. 7-8). Anderson's linkage of the cognitive and infrastructural foundations of nationalism to the structure of the novel recalls Erich Auerbach's conception of a humanist historical perspective that is fundamental to literary realism. In other ways it recalls György Lukács' theory of the essential relationship between literary realism and the "totality" of capitalism, a totality outside of which the social comes to defy imagination. In both these latter literary/historical paradigms, the styles of our narration of historical experience shape that experience, just as historical infrastructural conditions such as capitalism mold narrative styles.

If the nation finds a form of mimetic analogue in the novel, what kind of mimetic architecture might we associate with the kidnappings that launched the African diasporan movement into the colonial spaces of modern Western nations? Can we use any such analogy to help us locate and read texts that do not conform to the Anglophone model of the slave narrative, but that nevertheless represent slaves and former slaves? How might consciousness of diasporan kidnapping challenge our 
acceptance of national parameters for African diasporan literary studies in various languages, and our expectations of the kinds of genre and other textual characteristics that shape our "symbolic mapping of external social space?" How might we begin, in other words, to schematize the coming to literary and national consciousness for the African diaspora, catastrophically kidnapped into the spaces of New World modernity, not initially as partners in capitalist exchange, but as commodities?

Intuitively, Anderson's focus on the "Creole Pioneers" of New World nationhood would seem to open the door to consideration of the colonial African diaspora generally, and to the first postcolonial black New World nation, Hayti. However, although Anderson mentions Toussaint Louverture and the Haitian Revolution, they are forcefully relegated to the role of contrapuntal anecdote, because his argument relies on the concept of a linguistic and genealogical continuity between the New World and the European metropoles as the backdrop for the new imagining of communities.

For Anderson, the newly independent nations in the New World in the period from 1776 to 1838 provide the evidence for the association between novelistic and journalistic print capitalism and the national imagination, because unlike the European states that had transitioned from old to new regimes, these were "the first real models of what such states should 'look like' " (Anderson, 1994: p. 46); furthermore, they had "established their concepts of nation-ness [-] well before most of Europe" (Anderson, 1994: p. 50). Whether exemplified by "Brazil, the USA., or the former colonies of Spain," the "new American states of the late eighteenth and early nineteenth centuries" share for Anderson a crucial identity as places where:

Language was not an element that differentiated them from their respective imperial metropoles. All were shaped by people who shared a common language and common descent with those against whom they fought. (Anderson, 1994: p. 47)

This sharing of a common language and descent meant that New World creole "printmen" could travel back and forth between colonial and metropolitan spheres, disseminating literature and shaping new imaginings of the nation. For Anderson, this mediation, more than any European factor, contributed to the metamorphosis of New World colonies like the US into New World nations:

What I am proposing is that neither economic interest, Liberalism, nor Enlightenment could, or did, create in themselves the kind, or shape, of imagined community to be defended from these [metropolitan] regimes' depredations [...] In accomplishing this specific task, pilgrim creole functionaries and provincial creole printmen played the decisive historic role. (Anderson, 1994: p. 65)

This limited New World category of creoles sharing a "common language and common descent" starkly excludes both the African diaspora generally, lacking common descent and, often, common language with the metropole, and more specifically, the French 
colonial Americas, where creole status derived from birth in the colonies, regardless of African or European descent. In the French Caribbean colonies of the New World in the Revolutionary era, the term créole was generally synonymous with américain and designated anyone born in the colonies, whether of African or European descent. By contrast, in Latin America the term criollo, often also translated as "creole," referred to those born in the Americas but of unmixed Iberian descent; members of the African diaspora could not be creole in this context. Anderson's white creole printmen expanded the domain of a shared symbolic mapping of social space to introduce their own relatively autonomous psychological communities, emancipated from some of the most direct "depredations" of European metropoles, and also from some of the most radical extensions of European revolutionary imaginings.

The nation-building role of the creole printmen depended, according to Anderson, partly on their attempts to consolidate autonomous communities in order to deflect the Enlightenment metropolitan interest in modifying however minimally, to our eyes abusive power over slaves (Anderson, 1994: p. 49). "Far from seeking to 'induct the lower classes into political life," Anderson writes;

One key factor initially spurring the drive for independence from Madrid, in such important cases as Venezuela, Mexico, and Peru, was the fear of "lower-class" political mobilizations: to wit, Indian or Negro-slave uprisings. (Anderson, 1994: p. 48)

Thus, although Toussaint Louverture, by French Caribbean definitions, was a creole, and although the Haitian Revolution, as Anderson duly notes, "produced the second independent republic in the Western Hemisphere" (Anderson, 1994: p. 48), Haiti does not serve in Imagined Communities as an example of a "creole pioneer." Instead, it serves as an example of a catalyst for white creoles to reject European state interventions in a humanist mold.

Yet, the Haitian Revolution, can be seen as an especially useful model of a creole pioneer. Since the original publication of Anderson's book in 1983, historiography of the Haitian Revolution has confirmed in great detail that slaves and former slaves were instrumental in shaping revolutionary concepts of nation-ness, to the extent that modern nationalism, conceptualized without consideration of African diasporan contributions, may be, in Sybille Fischer's expression, "modernity disavowed." I am not the first, of course, to note the delimitations of Anderson's location of a new, national form of imagined communities in the Anglophone, Hispanophone, and Lusophone spaces of the colonial New World. Partha Chatterjee's (1993), The Nation and Its Fragments, targets the secondary role implicitly ascribed to the postcolonial nationalisms of Asia and Africa, and Andrew Parker and Harry Harootunian respectively return to this problem in the 2003 Grounds of Comparison. Not only had the New World colony of Saint-Domingue been built on the importation of kidnapped Africans, but its steady movement toward autonomy led to a phenomenon of Napoleonic kidnappings of prominent Haitians that is exemplary of a profound discontinuity of the "symbolic mapping of external social space." That discontinuity did not exclusively 
take the form of silence and non-dialogue, however, as Anderson's model might imply; it simply necessitates that we consider non-novelistic models of self-representation in early French-language literature by the African diaspora.

Within the Haitian and French Revolutionary eras from 1789 to 1804, the strange ballet of trust and hostility between the former slaves of Saint-Domingue and the French government led to moments when, for Napoleon Bonaparte and his associates, one black leader or another seemed to be France's best and fondest hope for an ongoing colonial future in Saint-Domingue, even in cases where these leaders clearly had been involved in earlier violent conflict with French colonial hierarchy. At other moments, when the primary fidelity of these black leaders to their own constituent communities became clear, it apparently became irresistible for the metropolitan power simply to seize and sequester members of the Haitian Revolutionary leadership or their families, in kidnappings that recapitulated the abusive deportations of the Middle Passage. But these leaders were already decisively exploiting the self-representational opportunities of print culture; their political strategies and individual poetics of anticolonial identity were blazing through the journalistic and political domains of key swathes of the Western world. In the context of deportations and captivity, their self-representations emblematized the structures of kidnapped narratives.

\section{Kidnapping le petit Christophe}

Compared to the kidnapping of Toussaint Louverture and his family, far less is known about the kidnapping episode involving the eldest son of the Haitian Revolutionary general Henry Christophe. Christophe, who served as president of the new African diasporan state from 1807-1811, and as King of Haiti from 1811 until his 1820 suicide, is commemorated in various creative works, including the Martinican writer Aimé Césaire's (1963), The Tragedy of King Christophe and the 2002 film Royal Bonbon by French-Canadian filmmaker Charles Najman. Accounts of Christophe's life generally speak of Prince Jacques-Victor-Henry (1804-1820) as Christophe's oldest son and heir, passing over the singular earlier episode in which the son of a Western leader was detained and died in captivity in another Western nation.

Young Ferdinand Christophe was voluntarily sent to France by his father in September of 1802 to be educated as a guest of the French government. The politics behind this arrangement are obscure; no direct correspondence in which Henry Christophe discusses his son is known to exist. Controversies of historical interpretation over Christophe's alignment with or resistance to the French government and its representatives in Saint-Domingue only indicate the contrasting ways in which one might speculate about his motivations in sending his eldest son to France following the French invasion of Saint-Domingue. As was evident in the case of Toussaint's sending of Placide and Isaac to France, paternal willingness to confer a child to France could mask complex negotiations with the French over movement toward autonomy on the part of black leaders in the colony. Christophe's willingness to send Ferdinand 
to France following the 1802 deportation of Toussaint and his family, and at a time when the blacks were locked in anticolonial hostilities with the French, seems very curious. It may have indicated a close collaborative relationship with the French in that period, or it may have indicated, on the contrary, a tenuous relationship in which it was necessary to make a potentially sacrificial gesture of good faith. (To some degree it is also, inevitably, an index of the paradoxical mobility and hybridity of various segments of colonial society in this era; this was, after all, the period in which the future father of Alexandre Dumas, born a slave to his French aristocratic father in Saint-Domingue, was serving as a high-ranking military officer in Napoleon's army, and when the eventual President of Haiti, Alexandre Pétion, had returned from his metropolitan military training to Saint-Domingue only as a part of Leclerc's invading army.)

Arrangements for Ferdinand's travels had begun in late 1801, prior to the dramatic rift between Christophe and the French upon the arrival of Leclerc's army in SaintDomingue in February of 1802. Discussion of the matter can be found in a manuscript copy of a letter to Christophe, contained in the ethnographer Moreau de Saint-Méry's Historical Notes, a sprawling collection of heteroclite archival materials. An 1814 notation at the top of the letter copy states that it was copied and returned unsealed to the Colonial Ministry before being delivered by General Leclerc to Saint-Domingue. The date on the copy is 19 Brumaire Year 10, or November 6, 1801. There is no signature or other identification of the author of the letter, so we cannot determine its origins with any certainty. The letter is unctuously flattering of Christophe's "submission" to France, of his interest in Europeans who had been "mistreated" by Christophe's superiors (presumably an allusion to the deportations of Sonthonax and Hédouville by Toussaint), and his centrality to France's efforts to bring about the "restoration" of Saint-Domingue:

[...] you demonstrate interest in the plight of my European confreres who have been mistreated by others $[\ldots .$.$] These and other qualities that distinguish you will not be lost$ on my country at this important moment; I have conveyed this to distinguished representatives of the most powerful of governments, which seems to have the single ambition right now of the restoration of St. Domingue; we are counting on your help, my dear general, for the success of this enterprise; and your beloved France will not be deceived. (Copie de la letter, 1801: p. 494-5)

The letter also establishes a strikingly personal tone, praising Christophe not just as a military officer, but also as a good father and spouse. The missive closes, "My sincere compliments to your wife, a thousand hugs to your little children; I will send information soon on the mentor who will accompany Ferdinand to France" (Copie de la letter, 1801: p.495).

In February, of course, general Leclerc would be deeply disappointed by Christophe's public statement of his allegiance to Toussaint, his refusal to permit the French to disembark, and his strategic burning of the Cap François to prevent the French from 
appropriating its resources. The correspondence between Christophe and Leclerc reproduced in Prince Sanders' 1818 Haytian Papers documents this phase of Christophe's relationship with the French. Leclerc wrote from his ship in the harbor;

I learn with indignation, Citizen General, that you refuse to receive the French squadron, and the French army that I command, under the pretext that you have received no orders from the Governer-General.

France has concluded a peace with England, and its governments sends to St. Domingo, forces capable of subduing the rebels; at least if any are to be found in St. Domingo. As to you, General, I confess it will grieve me to account you among them. (Letter from Leclerc to Christophe, 1969: p. 21.)

Christophe answered, with the same lucid distrust of colonial rhetoric and intentions that was documented in numerous journalistic accounts of the events, "The very mention of rebellion is an argument for our resistance" (Letter from Christophe to Leclerc, 1969, p. 25). This eloquent repartee demonstrated Christophe's understanding that Leclerc's usage of the term "rebellion" inherently implied an authority in relation to which the blacks' autonomy could only register as transgression.

Over the course of the following months, Leclerc had become confident, rightly or wrongly, in his success in "detaching" Christophe and Dessalines and their troops from Toussaint. He wrote to Napoleon on 6 June 1802 that he had "mastered the mind of Dessalines," a comment which, in light of later events, would appear to be both over confident and lacking in insight into the black leaders' abilities to engage in political maneuvering parallel to the French use of a rhetoric of hospitality in midinvasion (Letter from Leclerc to Napoleon, 1802: p. 161-2). In the days leading up to his arrest and deportation of Toussaint, Leclerc asserted that if he should fail to capture Toussaint, he would simply have him arrested by Dessalines and Christophe (Roussier, 1937: p. 162).

Leclerc's view of the submission of the black generals to his authority, no matter how dubious when framed on the continuum of both Dessalines' and Christophe's inspired rejections of French authority, often have been taken at face value in colonial historiography. A typical example of this tendency to conflate Leclerc's interpretation with historical reality can be found in Charles W. Mossell's (1896), Toussaint L'Ouverture, the Hero of Saint Domingo, where the author trenchantly reflected:

A traitor is always a traitor. After betraying Toussaint L'Ouverture, Christophe betrayed Leclerc as soon as the opportunity presented itself, and finally, under the influence of a treacherous spirit, took his own life. (Mossell, 1896: p. 271)

It is essential to consider the stresses that the black generals of Saint-Domingue were under to protect not only their political autonomy, but also their basic freedom, at virtually all moments of the Haitian Revolution. Their statements, contextualizing with prescience the fine line they had to walk at all times, are well documented by contemporary witnesses. One such statement by Christophe was transcribed by 
Pamphile de Lacroix. Christophe, who considered Pamphile to be a trustworthy source because of his republican military (rather than colonial) credentials, felt that he could speak to him frankly:

The revolt is gathering force because defiance is at its highest point. If you had the same epidermis as us, you would perhaps not share my confidence in sending my only son Ferdinand to general Boudet, to be raised in France. (de Lacroix, 1819: p. 226)

Christophe effectively points out that if Pamphile were black, he would be justified in viewing Christophe as foolhardy in sending his son to Paris; an implicit admission that, he himself, as a black leader, had doubts about the outcome of the arrangement. Beyond this statement, we also know that in September of 1802, Leclerc was discussing a plan to deport Henry Christophe himself to France. On 16 September, a disgruntled Leclerc wrote to Napoleon;

Christophe, to make up for the blunder of "uniting with the blacks," mistreated them so severely that they detest him, and I am going to send him off to you without the slightest fear that his departure will trigger an insurrection. I was not happy with him yesterday. (Roussier, 1937, 230)

Was the departure of Ferdinand Christophe partly a security against this threatened deportation of Henry Christophe himself? This would appear to be contradicted by a statement by Leclerc in a letter to Napoleon of 26 September. After stating that he lacked the strength to chase away the various black generals, and that he could only "maintain" them, he notes that Christophe inspired slightly more confidence in him than Dessalines, and that "I am sending his oldest son to France, whom he wants educated" (Roussier, 1937, 246). There are no subsequent contextualizations of Henry Christophe or Ferdinand's departures to France by Leclerc; his last letter to Napoleon was dated 7 October 1802, and he died of yellow fever three weeks later. One can at the very least conclude from the above statements, however, that the sending of Ferdinand to France was fraught with tensions over his father's basic political and personal autonomy. It is against this complex backdrop that the ostensibly consensual transfer by Christophe of his son Ferdinand to Paris occurred in late September of 1802. The fact that Leclerc sent the child within the timeframe he mentioned to Napoleon is confirmed in a later attestation from the Division of General Security (Division de sûreté générale) to the Ministry of the Interior in 1805 :

Mr. Lambert, ordered to appear before the Police Prefecture, declared that in the month of frimaire, Year 11 (September, 1802), his relative the abbot Collin, who resided at that time in the Cap Français, had sent him the son of Christophe, who was at that point ten years old, accompanied by the negress Marie. (The "negress Marie" was the 
It is after the first year of Ferdinand Christophe's education in France at the Collège de Justice on rue de la Harpe, that his story took a dark turn, leading to his internment in a state orphanage, La Pitié, and his eventual death there. This fatal detour from the consensual educational plan has not been addressed in any detail in biographies of Henry Christophe. The story did eventually unfold, however, in a handwritten transcription of a verbal testimonial by a former slave from Saint-Domingue, Praxelles, in papers belonging to Moreau de St.-Méry. Like the fragments of the memoirs of Toussaint Louverture that he had written out from memory and hidden in his headscarf to preserve his story, this mediated document is a kidnapping narrative that emblematizes the larger role of kidnapping in the African diaspora's entrance into the textual and print cultures of modernity.

Either Moreau de St.-Méry himself or an assistant transcribed Praxelles' statement in Paris in 1814, some years after the conclusion of the events in question. Praxelles, the wife of Charle Magne (a man whose name evokes the trend among slave owners of naming slaves for mythological or grand historical characters, in this instance after Charlemagne, crowned Emperor in 800), was a godmother to one of Henry Christophe's daughters. She was also linked to Henry Christophe's wife's sister Mademoiselle Marie, who served as Ferdinand's unofficial guardian in Paris, by a social bond between the family of her previous owners and the previous owners of Mademoiselle Marie. Praxelles' narrative pieces together an intricate fabric of acts of witnessing in a Parisian community that included numerous freed slaves interrelated by their relationships (sometimes biological and sometimes legal and social) to white colonial families and to each other; these complex overlaid relationships are represented partly through the affiliations of previous ownership, and partly through the codes of racial categories and African ethnic origins. Sisters and brothers identified in the narrative are clearly often half-siblings, contextualized separately. The document offers many traces of the variable social economic status of non-whites in Saint-Domingue and Paris, from the neighborhood of "Petite Guinée" or little Africa in Le Cap, to the alignment of Henry Christophe's sister-in-law with a certain Bishop Murielle in allegedly helping to persuade Christophe to send his son to Paris. The document gives a fragmentary but fascinating glimpse at the lives of free blacks from Saint-Domingue in Paris at the turn of the nineteenth century.

Praxelles' testimonial recounts that shortly after the arrival in Paris of Ferdinand with Marie-Louise Christophe's sister Mademoiselle Marie, they were brought by their governmental contact, Lambert, to visit the Consul himself, Napoleon Bonaparte, in the Tuileries. After Bonaparte questions Mademoiselle Marie at length, Lambert has a private interview with the Consul. The next day, Lambert explains to Marie that the child will be brought to a school some distance from Paris. She gives her consent on the condition that she accompany him, but wakes the next morning to find Ferdinand gone, which upsets her deeply: he has not departed, he has disappeared. She protests with great emotion, and is subsequently interned in the notorious asylum of La Salpêtrière. 
The details of what had happened to Ferdinand and Marie after their vanishing is then pieced together by this cast of witnesses: Praxelles; an elderly female street sweeper, race not specified; a Madame de St.-Joseph, the sister superior who orchestrates sewing jobs for inhabitants of La Salpêtrière, including Mademoiselle Marie; and a female companion of Madame de St.-Joseph. One day, Madame de St.-Joseph and her friend see a young man standing guard at the entrance to the state orphanage La Pitié next to the Jardin des Plantes, and they instantly recognize him as Christophe's son. He joyfully confirms his identity, "Yes, it's me," and is promptly knocked over by blows from a supervisor. After this, indirect narration representing hearsay takes over, as no one previously identified in the document directly sees Christophe again, and yet information trickles out. Ferdinand, we learn, is known to have resisted being trained as a cobbler, insisting instead on his right to an education, and asserting his father's relationship with Napoleon. His continued insistence that his father was not a brigand who was massacring the whites of Saint-Domingue, but a friend of Bonaparte, led to the repeated beatings from which he eventually died. Mademoiselle Marie, according to this narrative, died soon after. Lambert, the French middleman, had in the meantime enriched himself with the small fortune sent to Paris with his son by Henry Christophe.

What follows is a transcription (with minor updating of spelling and punctuation) and translation of Praxelles' narrative in its entirety:

[Henry] Christophe is a Creole negro or griffe from the island of St. Kitts. He was brought by his English master to Cap Français in Saint-Domingue. This master was the longtime owner of the Café de la Couronne on Espagnole Street where Christopher worked.

After the burning of the Cap, Christophe, now free, wanted to marry the woman who is today his wife. She is the daughter of a rich and highly esteemed free black who lived in the Cap in Petite Guinée [Little Africa] in the neighborhood of the Café de la Couronne. This father, named Codary, turned down Christophe, who only was able to take his wife after her father's death.

This woman had a sister who had belonged, like the rest of the family, to a white family from the Maurin neighborhood who gave them their freedom.

This white family, having returned to France, brought with them Bonaire, the brother of Madame Christophe, and also Bonaire's sister, who in France was known as Mademoiselle Marie.

Mademoiselle Marie was raised in a convent in Paris with some young ladies from the family of her former master.

In Paris, Bonaire married Cécile, the negro daughter of Flore, Madame Bouroust's Arada negress. Cécile was the sister of Adelaide who was also a daughter of Flore, but a mulatta.

Bonaire and Mademoiselle Marie went back to Saint-Domingue when General Leclerc arrived there. Together with Bishop Murielle they convinced Christophe to send his son, who was about ten years old, to be raised in Paris.

Christophe entrusted the care of his son to his sister-in-law Mademoiselle Marie, and

Bishop Murielle gave him a letter of recommendation for a Monsieur Lambert who was his best friend and who would take care of them. 
Mademoiselle Marie and her young nephew Christophe arrived at the home of Monsieur Lambert who was then a clerk of Monsieur de la Marinière, a justice of the peace at the Porte St. Honoré.

The new arrivals came laden with gold, jewels, and merchandise that Christophe had given them in abundance.

Only a few days later, Lambert took the child and Mademoiselle Marie to the Bonaparte residence in the Tuileries, where Bonaparte received them very well and questioned Mademoiselle Marie at length.

When the child and his aunt had left Bonaparte, Lambert went in to see Bonaparte, and then they all went back together to Lambert's.

The next day, Lambert told Mademoiselle that Bonaparte wanted Christophe's son to be raised sixty leagues outside of Paris. The aunt said that she would follow her nephew there, but the next day the child had left. Upon awakening, Mademoiselle could find no trace of him, and was deeply upset.

Lambert answered that he had wanted to avoid a painful farewell and that as for Mademoiselle Marie, he was going to send her to an establishment in Paris where she would enjoy every advantage she could wish for.

And in fact, shortly afterward he had her get into a carriage, had a packet of belongings prepared for her, and escorted her to La Salpêtrière.

Mademoiselle Marie had known a woman named Praxelles, the wife of Charle Magne, firstly because Praxelles was the godmother of one of Christophe's daughters and secondly because Praxelles was linked to Bonaire's wife through the relationship between the Baroness Bouroust and the la Barre family, [the family of] Praxelles' former mistress. Praxelles had visited Mademoiselle Marie and her nephew upon their arrival in Paris; she was therefore extremely surprised to have no more word of them and sought in vain to have news of them.

Long afterward, an old female street sweeper from the neighborhood came to see her and told her that Mademoiselle Marie was in La Salpêtrière. She told Praxelles that she would only be able to see her with great ingenuity, and that she should feign to bring sewing work to Madame de St.-Joseph, the mother superior.

Praxelles followed these instructions and visited Madame de St.-Joseph where she found Mademoiselle Marie, who, when she recognized her, collapsed and dissolved in tears, telling her that she was shut up in this place and could not go out or confer with anyone.

Later, Madame de St.-Joseph and a female companion were walking in the Jardin des Plantes when they saw a young man standing guard at the gate of La Pitié. Because of what Mademoiselle Marie had told them about Christophe's son, they went over to him, crying out, "Here is the son of Christophe." The young man joyfully said "Yes it's me." But in that same moment a man who was at the gate of La Pitié gave Christophe two powerful blows that made made Christophe drop his rifle, and fall over, after which it was necessary for him to retreat inside.

It was impossible to catch a glimpse of him from this time forward, but it is known that they set him to learn the trade of shoe making, required him to take it up. Christophe continually refused, saying that his father had sent him to France to get a fine education, not to be a cobbler. They responded the same way they had the day Madame de St.-Joseph saw him, telling him that he was a little brigand, the son of a 
bigger brigand who was massacring all the whites in Saint-Domingue; the young adolescent responded in his turn that his father was not a brigand, but a friend of Bonaparte.

This response, and his obstinate refusal to become a cobbler, were the reasons that Christophe was beaten so much that he developed several abscesses, of which he died.

As to Mademoiselle Marie, overwhelmed with grief and regrets, she died at $\mathrm{La}$ Salpêtrière soon after her nephew.

Upon her death, Lambert had some old rags, an old silver goblet and pot, and six piastres gourdes brought to the hospice, saying that this was all she had had left.

As for himself, he did not delay in buying a lovely house on the Champs Elysées, which he furnished richly. He also bought a lovely property and he displayed everywhere a level of luxury which he more than likely owed to the deaths of the little Christophe and Mademoiselle Marie.

This was recounted to me by Praxelles herself, Monday the twenty-fourth of October, 1814. (Praxelles narrative, 1814: p, 89-93)

Praxelles' narrative contains some details that are inaccurate; notably, the chronology of Ferdinand and Marie's respective internments, which occurred not a few days after their arrival in the fall of 1802, but a year later. As Servant's article documents, official correspondence cited the admission to La Pitié of Ferdinand Christophe, by order of the Minister of the Marines and of the Colonies and of the Minister of the Interior (in other words, as orchestrated through the French government at its highest ranks), on 23 December 1803, not 1802. It also errs in the chronology of Mademoiselle Marie's death, which Praxelles attributes to heartbreak following the news of the death of Ferdinand. In reality, Ferdinand, aged twelve, was still alive and a prisoner of La Pitié on 8 July 1805, when Mademoiselle Marie died in La Salpêtrière. The actual date of the death of Ferdinand Christophe is not currently known. Praxelles' testimonial also departs from other records in terms of some names; Lambert would state the name of the clergyman who assisted in arranging Ferdinand's voyage to Paris as the abbot Collin, whereas Praxelles cites a bishop Maurielle. Most biographers of Christophe cite his wife's maiden name as Coidavic, whereas Praxelles lists Codary.

And yet: Praxelles' mediated narrative is the single known historical account of a shocking episode that is confirmed in the essential details of Christophe's aborted schooling, and his involuntary removal by order of the French government, to a state orphanage where he was kept captive, despite the presence in both Paris and SaintDomingue of relatives willing, and able, to take care of him. Praxelles was also correct in the basics of her story of the forced admission to La Salpêtrière of Henry Christophe's sister-in-law Marie; Servant in 1913 noted that historical records of La Salpêtrière do confirm the admission (n. 130, fol. 15 r.) and death (n. 29, fol. 15 v.) there of Mademoiselle Marie. What Praxelles apparently did not know was that the French government had documented - and denied - charges made by Ferdinand that Lambert had appropriated his and Mademoiselle Marie's funds and belongings after the death of Mademoiselle Marie, precisely along the lines of the allegations in Praxelles' story (although it is clear that Praxelles' account of Lambert's profit is exaggerated). ${ }^{6}$ 
Ironically, in an exact parallel to the case of the Louverture children and the contentions by French police that they needed to keep Isaac and Placide in Paris despite their father's request for their return because of the threat that they might be kidnapped back to Saint-Domingue, officials in Paris responded to Ferdinand's accusations by focusing on an alleged plot to kidnap Ferdinand out of the orphanage and back to his parents. When they inquired of Lambert about his use of the funds mentioned by Ferdinand, they simultaneously requested that Lambert take care to prevent the kidnapping of Ferdinand: "he should furthermore take all necessary precautions to prevent this kidnapping" (Letter from the Minister of the Interior to the Minister of the General Police, 1913: p. 228-9). The alleged plot was explained in an explanatory note sent to the police prefect:

We are informed that an American captain had taken on the responsibility a while ago of kidnapping the young Ferdinand and sending him to the United States and thence to Saint-Domingue, but that this captain, noticing that he had aroused suspicion, had left precipitously without carrying out his plan. This last piece of information coincides perfectly with the declaration of the negress Marie. ("Letter from the Minister of the Interior to the Minister of the General Police, 1913: p. 228-9)

In this account, the detail that Mademoiselle Marie had provided a statement about an alleged kidnapping is both tantalizing and chilling; it demonstrates that she had, from inside La Salpêtrière, remained in touch with international dealings concerning her nephew, and also that she had been interrogated about her knowledge. Henry Christophe was no doubt the first President and King in the Western hemisphere to rule without ever breathing a public word about the abduction and death of his heir at the hands of another Western government.

\section{Kidnapped Narratives}

How do documents such as the mediated testimonial of Praxelles represent Haiti as a different kind of "creole pioneer," articulating a different kind of new nationalism - revolutionary-era black postcolonial nationalism - in which the imagining of communities does not conform to the model established by Benedict Anderson? In effect: here nation is to novel as kidnapping is to mediated and disguised witnessing. These are liminal texts. The narrative by Praxelles, unpublished for one hundred years (and then only published in the most obscure of sources), was told by a witness for posterity, transcribed by a secretary or ethnographer, and represented the historical knowledge of people whose social existence could be effectively erased when struggles for autonomy created "race" conflicts, labeled at the time in terms of "brigands" and "massacres." The proclamation by Toussaint is one of many texts that show his distinctive strategic brilliance, melding the conciliatory and the subversive to outmaneuver his opponents; these mediated texts were disseminated extraordinarily broadly 
through journalism, and yet have not been credited to Toussaint as the political "writings" of a major figure on the revolutionary world political stage.

Kidnapped narratives of the African diaspora in the revolutionary era do not take the form of novels, and they are often textual rather than print culture: its documents lurk in archives, newspapers, records, and even quotations in other works, in the various forms of fragments, edited popular oral literature, and mediated political proclamations and correspondence. Its messages were sometimes, as in the memoirs of Toussaint, precisely kidnapped: contained and isolated. At other times, as in the proclamations and correspondence of Toussaint and Dessalines, they were a Western print culture sensation. They are a corpus that must be researched outside of the framework of the novelistic masterpiece of national literatures, or even of the slave narrative shaped and cultivated by abolitionist "printmen," despite abundant overlap with that genre. This diasporan literature by those whose common descent involves kidnapping gives us a new point of entry to exploration of the nation, as not just an imagined community beyond face-to-face interaction, but as an imagined community with unimagined participants, who were subject to the lawless silencing of their voices and public existence, but who nevertheless persevered in selfrepresentation. Kidnapped narratives represent one part of the answer to Laurent Dubois' provocative question of how we might "write an intellectual history of the enslaved" (Dubois, 2006: p. 3).

\section{ACKNOWLEDGEMENTS}

This article contains material included in my book; Jenson, Deborah. (2011). Beyond the Slave Narrative: Politics, Sex, and Manuscripts in the Haitian Revolution. Liverpool University Press.

1 The metaphor of the "tree of liberty" harkened back to the celebration in Revolutionary SaintDomingue of the anniversary of the French abolition of slavery around a large tree, "l'Arbre de la Liberté" (Roume 1). There are many accounts of the scene in which this quote was produced, including the following narrative by Pamphile de Lacroix: "He addressed these memorable words to the division chief Savary, commander of the vessel: 'In overthrowing me, they have only knocked over in SaintDomingue the trunk of the tree of the liberty of the blacks; it will grow back by the roots, for they are deep and numerous' “ (203).
2 Journalistic accounts vary slightly in the wording of the tree of peace quote. In fact, Aristide first quoted Toussaint Louverture and than adapted that quote. His statement was translated simultaneously into English by an intermediary whose voice obscures Aristide's French speech in the audio transcript. For the translated transcript of the address, see "Aristide Details Last Moments in Haiti."

3 A photograph of Aristide's actual letter is available in "Aristide's Resignation Letter" (http://edition.cnn.com).

4 This and all other translations from French are my own unless otherwise indicated. 
5 These texts are anthologized in Northup's The Atlantic Slave Trade.
6 Letters on these matters, dated July 5, August 3, and August 9 1805, are in CHAN F7 6461.

\section{References ANd Further Reading}

Anderson, Benedict. (1994). (Original work published, 1983). Imagined Communities: Reflections on the Origin and Spread of Nationalism. London and New York: Verso.

Aristide Details Last Moments in Haiti, Calls for Stop to Bloodshed in First Address to Haitian People From Exile. (2004). <http://news. pacificnews.org/news/view_article. html?article_id=68ea078d4f916517e92ee1c3 36d32285>. Accessed 10/05/10.

Aristide's Resignation Letter, CNN (http:// edition.cnn.com). 2nd March, 2004.

Byrd, Jennifer. (2004). K.U. Prof asked to translate Aristide's statement. Lawrence Journal-World. http://www2.1jworld.com/news/2004/mar/11/ ku_prof_asked/. Accessed 10/05/10.

Chatterjee, Partha. (1993). The Nation and Its Fragments: Colonial and Postcolonial Histories. Princeton: Princeton University Press.

Cheah, Pheng and Jonathan Culler. (2003). Grounds of Comparison: A round the Work of Benedict Anderson. New York: Routledge.

Copie de la lettre écrite au Général Christophe, Remise décachetée au Ministre de la Marine pour être Portée par le Général Leclerc à St. Domingue. Notes Historiques de Moreau de St. Méry, AOM F3.141: 494-5.

Davies, Norman. (1996). Europe: A History. Oxford and New York: Oxford University Press.

de Lacroix, Pamphile. (1819). Mémoires pour servir à l'bistoire de la révolution de Saint-Domingue. Vol. II. Paris: Pillet aîné.

Dubois, Laurent. (2006). An Enslaved Enlightenment: Re-Thinking the Intellectual History of the French Atlantic. Social History, 31, 1-14.

Fischer, Sybille. (2004). Modernity Disavowed: Haiti and the Cultures of Slavery in the Age of Revolution. Durmam: Duke University Press.

Harootunian, Harry D. (2003). Ghostly Comparisons: Anderson's Telescope. In Pheng Cheah and Jonathan Culler. Grounds of Comparison: Around the Work of Benedict Anderson, pp. 171-90. New York: Routledge.
Kemedjio, Cilas. (2005). Du Bateau négrier à l'avion négrier: Haïti, les puissances esclavagistes et le monde noir. Présence francophone, 64, 101-30.

Labat, J.-B. (1993). Voyage aux isles (Chronique aventureuse des Caraïbes, 1693-1705). Paris: Editions Phébus.

Letter from Christophe to Leclerc. (1969). In Prince Sanders (Saunders). Haytian Papers 1818: An Address Delivered at Bethel Church. Philadelphia: 1818. A Memoir Presented to The American Convention or Promoting by the Abolition of Slavery. 1819. 13 Pluviose Year 10. Philadelphia: Historic Publications, 238, 25.

Letter from Leclerc to Christophe. (1969). In Prince Sanders (Saunders). Haytian Papers 1818: An Address Delivered at Bethel Church. Philadelphia: 1818. A Memoir Presented to The American Convention or Promoting by the Abolition of Slavery. 1819. 13 Pluviose Year 10. Philadelphia: Historic Publications, 238, 21.

Letter from Leclerc to Napoleon. (1802). In Paul Roussier, Lettres du General Leclerc: Commandant en Chef de l'Armée de Saint-Domingue en 1802. Paris: Société de l'Histoire des Colonies Françaises et Librairie Ernest Leroux, 1937: 161-2. [Letter dated 6 June 1802.]

Letter from the Minister of the Interior to the Minister of the General Police. (1913). In George Servant, "Ferdinand Christophe, fils du roi d'Haïti, en France." Revue de l'bistoire des colonies françaises, n. 23, 228-32. Manuscript letter dated 13 frimaire an 13 (31 August 1805), CHAN F7 6461.

McLaughlin, Eliott C. (2004). Aristide tells AP the US forced him out. <http:// www.fanmilavalasny.com/main $1 / \mathrm{AP}_{\text {_ }}$ press.html>. Accessed 10/05/10.

Mossell, Charles W. (1896). Toussaint L'Ouverture, the Hero of Saint Domingo: Soldier, Statesman, Martyr, Or, Hayti's Struggle, Triumph, Independence, and Achievements. Lockport: Ward and Cobb.

Northrup, David, ed. (1994). The Atlantic Slave Trade. Lexington: DC Heath. 
Parker, Andrew. (2003). Bogeyman: Benedict Anderson's 'Derivative' Discourse. In Pheng Cheah and Jonathan Culler. Grounds of Comparison: Around the Work of Benedict Anderson, pp. 53-74. New York: Routledge.

Praxelles' narrative. Notes Historiques de Moreau de St. Méry. Aix-en-Provence, France: Archives d'Outre-mer. M, F3 140bis, 89-93.

Roume, Agent. (1798). "Discours," 16 Pluviôse An 7 (Port-Républicain: Gauchet et Co., 1798), 1.

Roussier, Paul. (1937). Lettres du General Leclerc: Commandant en Chef de l'Armée de saint-
Domingue en 1802. Paris: Societé de L'Histoire des Colonies Françaises et Librairie Ernest Leroux.

Slevin, Peter and Scott Wilson. (2004). Aristide's departure: the US account. The Washington Post. 3 March 2004: A19.

Williams, Carol J. (2004). Reality puts damper on Haiti's bicentennial party. Seattle Times. 2 January 2004. <http://community.seattletimes. nwsource. com $/$ archive $/$ ? date $=20040102 \&$ slug $=$ haiti02>. Accessed 10/05/10. 